\title{
The New Racial Politics of Welfare: Ethno-Racial Diversity, Immigration, and Welfare Discourse Variation
}

\author{
Hana Brown. Ph.D. \\ Wake Forest University \\ brownhe@wfu.edu.
}

Keywords: TANF, welfare, race, immigration, discourse

\begin{abstract}
$\underline{\text { Abstract }}$
Research on race and welfare focuses largely on characterizations of black and white welfare recipients. Few studies examine racialized welfare discourse beyond the black-white divide. Employing media and archival data from four states during the 1996 welfare reforms, this study finds variation in welfare discourse depending on the perceived race of the beneficiaries. Existing work emphasizes the prevalence of a morality discourse about lazy and hyper-fertile black recipients, which this study finds predominant in Alabama and Georgia. In California and Arizona, where debates centered on Hispanic, Asian, or Native American recipients, discourse about law-and-order and economic opportunity prevailed. These types of discourse varied in racial character and in their claims about the causes of and solutions for welfare participation. Policymakers used the morality discourse to demand punitive welfare regulations, while the law and order and economic opportunity discourses were used to promote immigration enforcement and economic development, respectively.
\end{abstract}


The US population is undergoing profound transformations. In 2012, non-white births outnumbered white births for the first time in history. With on-going immigration and concomitant growth in the Asian and Latino populations (Frey 2011), US Census officials now predict that the country will be "majority minority" within 30 years (Morello and Mellnik 2012). Researchers have begun to ask how these changes will affect the racial fabric of the country, including the highly racialized world of welfare politics (Reese and Ramirez 2002; Fox 2004; Brown 2013).

Existing research on race and welfare politics offers little insight into variation in welfare discourse about different minority racial groups. It focuses almost exclusively on black-white relations, examining how black caseload demographics (Monnat 2010; Soss, Fording, and Schram 2011; Weaver and Gais 2002) and media portrayals of black welfare recipients (Gilens 1999) affect public support for cash welfare. Studies of racialized welfare discourse also follow a black-white model, examining policymakers' and the media's use of Ronald Reagan's “welfare queen" stereotype: a scheming, hyper-fertile, and lazy black single mother (Hancock 2004; Neubeck and Cazanave 2001). While these studies are pivotal to understanding contemporary welfare politics, they pay little attention to how race relations and racial attitudes relate to welfare beyond the black-white divide. With changes in national demographics and the racial composition of welfare caseloads (Cherlin et al. 2009), the politicization of Latino, Asian, and Native American welfare participation is of both scholarly and public importance.

This exploratory study examines whether the discourse used to characterize Latino, Asian, and Native American welfare recipients differs from the longstanding one about black work ethic. ${ }^{1}$ It also asks whether distinctive policy prescriptions accompany race-specific discourses.

\footnotetext{
${ }^{1}$ I use "discourse" to refer to explanations for individual or group welfare participation, elsewhere in the paper referred to as causes of welfare participation.
} 
To answer these questions, this article examines media and policy responses to the 1996 welfare reform act in four states with diverse racial compositions: Alabama, Georgia, Arizona, and California.

This study employs newspaper content analysis and archival data, and finds that while policymakers deployed racialized discourse to malign welfare recipients in all four states, discourse content differed dramatically depending on the race of the beneficiaries under discussion. Lawmakers and the media expressed different assumptions about the causes of welfare use and suggested different policy solutions depending on the race of beneficiaries

\section{The Discursive Politics of Welfare}

Studies of discursive politics are a critical part of welfare state scholarship. Researchers in this area parse out the language that welfare recipients use to explain their understandings of work, poverty, and welfare participation (Lens and Cary 2010; Woodward 2008). Ethnographic and historical studies reveal the gendered and racialized ways in which case managers characterize their jobs, their clients, and social citizenship (Korteweg 2006; Park and Kemp 2006; WatkinsHayes 2009). As analyses of the broader public discourse around welfare show, from the earliest days of the US welfare state, the frames used by the media, public officials, and citizens in policy debates have interacted with political, institutional, and economic factors to structure welfare policy outcomes (Schram 1995; Mink 1996; Neubeck and Cazanave 2001; Reese 2005; Fox 2012).

Recognizing the potential consequences of welfare discourse for anti-poverty policy and the lived experience of welfare recipients, many researchers are concerned with cultural characterizations of poverty, dependency, and family and how they shape contemporary politics. 
Past studies reveal longstanding and contentious battles over the meaning and consequences of welfare use (Curran 2002; Fraser and Gordon 1994; Haney and March 2003; Little 1999; Mink 1996; Neubeck and Cazanave 2001; Toft 2010). For much of the $20^{\text {th }}$ century, welfare discourse largely depicted poverty as an individual flaw rather than a result of structural inequality (Gordon 1994; Mink 1996; Weir 1990), bolstering a welfare system that relegated poor ethnoracial minorities to the weakest social programs while preserving a more generous safety net for white male workers (Lieberman 1998). Welfare discourse also made moral judgments about welfare recipients a central component of welfare politics and policymaking (Hancock 2004). Not surprisingly, stereotypes of blacks' work ethic are strongly related to anti-welfare sentiment in the United States (Gilens 1999; Fox 2004).

There is broad consensus that in the late $20^{\text {th }}$ century, welfare discourse converged around the racialized and gendered construction of "the welfare queen" (Fox 2004; Hancock 2004; Neubeck and Cazanave 2001). President Reagan coined the term during his 1976 presidential campaign when he described the "welfare queen" as someone who "has eighty names, thirty addresses, twelve Social Security cards and is collecting veteran's benefits on four non-existing deceased husbands. And she is collecting Social Security on her cards. She's got Medicaid, getting food stamps, and she is collecting welfare under each of her names" (Staff Writer 1976, 51). Using media and legislative content analysis, Ange-Marie Hancock (2004) finds that stereotypes about welfare recipients' fecundity and laziness resurfaced systematically during the 1996 welfare reform debates, reinforcing advocacy for punitive policies.

The analytic emphasis on black and white welfare participants has deflected attention away from the racialization of Asian, Latino, and Native American welfare beneficiaries. This oversight is noteworthy given demographic transformations in the US population and emergent 
scholarship on the new world of racialized welfare politics. Not only are US racial demographics changing, a larger proportion of whites than non-whites have disappeared from TANF, leaving many states with caseloads comprised disproportionately of people of color (Cherlin et al. 2009; Loprest 2002; Mauldon, Speiglman, and Stagner 2012). However, most research continues to look at welfare use in terms of black and white and presumes that the stereotypes associated with black welfare use also apply to other minority groups, just with less intensity (Fox 2004; Soss, Fording, and Schram 2011). No study systematically examines whether and how welfare discourse varies by the race of assumed beneficiaries.

\section{Research Design and Methods}

This study examines racialized welfare discourse in four states during the mid-1990 welfare reforms. The Personal Responsibility and Work Opportunity Reconciliation Act (PRWORA) marked the most important shift in federal welfare policy since the 1960s. It terminated the entitlement program, Aid to Families with Dependent Children (AFDC), and implemented the block grant, Temporary Assistance for Needy Families (TANF). In addition to requiring work participation from welfare recipients, welfare reform enacted strict sanctions for noncompliance and placed time limits on welfare receipt. It also categorically denied AFDC/TANF, food stamps, and Social Security Insurance to many non-citizens. Over half of welfare reform's cost savings measures were projected to come from cuts to non-citizen benefits (Hagan et al. 2003).

Welfare reform laid out a broad set of parameters for states to follow in implementing their new welfare policies, but it also gave states flexibility to make programmatic decisions. As a result, in the mid-1990s policymakers in all fifty states reflected on local poverty conditions and crafted state-specific anti-poverty measures. After the act's passage, state legislatures 
around the country reassessed their welfare policies, creating conditions ideal for analyzing variations in the social construction of welfare beneficiaries across state and racial lines (Soss et al. 2001).

I analyze welfare reform discourse in four demographically diverse states: Alabama, Georgia, Arizona, and California. To maximize variation in the race of beneficiaries featured in welfare discourse, this exploratory study purposively selected states based on the racial composition of their caseloads. ${ }^{2}$ In the mid-1990s, the vast majority of Alabama and Georgia TANF recipients were black, Arizona had large and long-standing Hispanic and Native American recipient populations, and California had large Hispanic and Asian recipient populations (see figure 1 for a breakdown of caseloads by race in each state). These states are not necessarily representative of patterns elsewhere, but the comparison allows an assessment of how racialized welfare discourse may vary by the race of welfare beneficiaries and whether racespecific characterizations of welfare beneficiaries accompany different policy prescriptions.

To address these issues requires data on public and policymaker welfare discourse that can be analyzed for frequency and co-occurrence of three distinct themes: the race of the welfare beneficiaries under discussion, the perceived causes of welfare participation, and the proposed solutions for welfare participation. ${ }^{3}$ Previous research uses news media content analysis to assess the prevalence of racialized portrayals of policy beneficiaries and the characterization of social problems (Gilens 1999; Misra, Moller, and Karides 2003; Hancock 2004; Chavez 2008; Best 2010). Such detailed analysis allows researchers to parse out the specific characteristics attributed to policy beneficiaries (Hancock 2004) and to measure whether these characteristics

\footnotetext{
${ }^{2}$ Caseload demographics are not a perfect indicator of racialized welfare discourse. However, debates about Hispanic, black, and European immigrant welfare recipients have historically been far more prevalent in areas with high concentrations of those populations (Fox 2012).

${ }^{3}$ According to Benford and Snow (2000), two critical tasks for policymakers and advocacy organizations are to identify the cause of a social problem and offer a solution that addresses the cause.
} 
are more frequently associated with some social groups than others (Misra, Moller, and Karides 2003). Following this precedent, I conduct media content analysis to analyze the extent to which a traditional racialized morality discourse was used in these states that vary in their racial composition. ${ }^{4}$ I pair this content analysis with analysis of archival policy evidence in order to assess whether a morality discourse was prevalent in the states' policy debates about welfare reform and to explore the possibility that alternative racialized welfare discourses emerged to reflect changing demographics in these states. The archival analysis also permits a clear analysis of the proposed policy solutions that accompanied different types of racialized discourse (Hancock 2004).

The first stage of the study involves a content analysis of 1,000 welfare-related news stories in the largest paper in each state from 1993-1997: the Birmingham News, the Atlanta Journal-Constitution, the Arizona Republic, and the Los Angeles Times. These years mark the height of welfare debates at both the federal and state levels. ${ }^{5}$ The newspapers were the largest in their states at the time, their circulation extended statewide, and stories from each paper were routinely carried by local publications. To create the sample of stories, a research assistant and I searched for articles containing the term "welfare" for each state in each year. We retained only those stories that both used the term "welfare" to refer to means-tested assistance for low-income individuals and referred to the state in question, randomly selecting fifty stories per state per year to create the final dataset. To map the structure of media discourse, we used Atlas.ti to code the

\footnotetext{
${ }^{4}$ The coding scheme also tracked the prevalence of non-racial discourses. In Arizona, California, and Georgia, racialized discourses were far more prevalent than non-racial ones. In Alabama, racialized discourses were second to a budget-based discourse citing limited funds for welfare services. Because the data on non-racialized discourses revealed little variation across the states, I confine my focus in this paper to racialized discourses. ${ }^{5}$ Although Congress officially took up the issue of welfare reform in 1995, state-level debates about Clinton's promised reforms began in 1993. All states had finalized their new welfare programs by 1997.
} 
articles. For each state-year, one of us coded the even numbered stories and the other coded the odd.

I use this dataset to assess different types of racialized discourse in the media and to test empirically whether the traditional morality narrative about black fertility and laziness were equally present across the four states. To measure the extent to which these stereotypes were present in state-level news reporting, my research assistant and I used a modified version of Hancock's (2004) coding scheme for stereotypes about welfare recipients (See table 1). ${ }^{6}$ To determine whether and how these welfare stereotypes were racialized, we coded for racial markers employed in media discourse (See table 2). These codes identified when articles explicitly noted the race of an individual, organization, or group of individuals. The intercoder reliability rating for these codes and for the stereotype codes ranges from 88 to 100 percent.

Using Atlas.ti, I measured the frequency of each code in each state as well as the cooccurrence of stereotype and race codes. Overall, close to 70 percent of the individual articles contained at least one racialized welfare stereotype. I report the results using the paragraph, not the article, as the unit of analysis (referred to as the "quotation" in Atlas.ti). Unlike article-level coding, coding by paragraph allowed me to separate out multiple and even contradicting types of discourse within single stories (Hancock 2004). For example, a news story could contain two paragraphs, one where a governor argues that black welfare recipients are lazy and another in which a caseworker suggests that Asians are a drain on public resources. Coding by story would show that that "black, Drain Collective Resources, Asian, and Lazy/Don't Work" codes all cooccurred. In reality, black and Lazy/Don't Work codes co-occurred and the Drain Collective Resources and Asian codes co-occurred. Coding by paragraph permits me to distinguish these

\footnotetext{
${ }^{6}$ Hancock distinguishes between moral judgments about welfare recipients and welfare stereotypes, but this distinction is not relevant for my analysis. I condense her 14 codes into 11 stereotype codes.
} 
co-occurrences and, therefore, to identify specific racialized discourses. Quotation-level analysis is the only way to meaningfully examine the co-occurrence of race and stereotype codes, but this coding strategy is not without disadvantages. Because newspaper paragraphs are often equivalent to one or two sentences, the use of quotations as the unit of analysis may underestimate the frequency of different codes by increasing the total units of analysis. ${ }^{7}$

Most studies of welfare discourse rely on media analysis (Gilens 1999; Misra, Moller, and Karides 2003), but assessing the types of discourse used by policymakers is also critical to determining how pervasive these characterizations of welfare recipients are, and whether they are used to justify specific policy interventions. To analyze policy discourse, I supplement media content analysis with extensive archival research, collecting and analyzing over 1,500 pages of archival materials from across the four states. I consulted collections at the California State Archives, the California Regional Oral History Office, the Arizona State Library and Archives, the Arizona State University Library Special Collections, the Arizona State Senate and House of Representatives, the Georgia State University Library Special Collections, the Georgia Archives, and the Alabama Department of Archives and History. At each location, I examined files from the committees charged with crafting reform legislation and any collections indexed with the words "welfare reform." I also reviewed the papers of the governors, legislators, advocacy organizations, and individual activists whose names repeatedly appeared in the news content analysis and in other archival documents. In addition, I analyzed transcripts of legislative testimonies, committee meeting minutes, speeches, and press releases, since these materials are the most representative, credible, and accurate presentations of policy discourse

\footnotetext{
${ }^{7}$ In paragraph-level coding, a small number of excessively long or code-dense articles can bias the sample. I examined the dataset to identify articles meeting these criteria and identified only one such article: an expose on illegal practices by Mexican immigrants published in the Arizona Republic. I removed this article from the dataset and replaced it with the next article from the random sample.
} 
(Mariampolski and Hughes 1978; Scott 1990). As with the newspaper content analysis, I only analyzed archival documents about each specific state in question. Documents of questionable origin or authenticity were checked for validity against other historical, newspaper, or interview sources and disregarded in the absence of external validation (Mariampolski and Hughes 1978). ${ }^{8}$ Unlike newspaper content analysis, archival data cannot yield quantifiable results because different types of state records are not necessarily comparable. ${ }^{9}$ Archival data from policy records did permit me to assess the emergence of discourse in policy debates, to elucidate the key features of such discourse, and to track variation in the racialization of welfare discourse and policy prescriptions. Analysis of these archival documents occurred in three stages. I first coded these documents using the same race and welfare stereotype codes employed in the media content analysis. In the second stage, I reviewed the archival materials again to inductively generate codes for causes of and solutions to welfare participation. This analysis yielded the cause/blame codes for lax immigration enforcement, limited job opportunities, inadequate domestic violence supports, absent fathers, limited personal motivation, criminal tendencies, over-fecundity, and a permissive welfare system. It also yielded a range of solution codes including immigration reform, casino construction, benefits termination, child care and transportation assistance, and TANF privatization. In the final stage of document analysis, I attempted to identify whether the cause, race, and solution codes co-occurred in meaningful

\footnotetext{
${ }^{8}$ In some cases, I supplemented archival data with semi-structured interviews with state welfare reform leaders. I used this data to fill gaps in the legislative and advocacy histories I constructed from media and archival data and to verify data retrieved from the archives. Interview schedules are available upon request.

${ }^{9}$ Archival materials are a more accurate data source for analyzing policy debates and discourses than newspapers. These data offer rich qualitative data but preclude an absolute measure of code frequency because archival sources vary in their credibility and influence. A campaign ad, personal notes made by a policymaker, and internal legislative memo are not comparable in their audience or their reach. Newspaper stories are also varied (op-eds, for example, are different from feature stories), but, unlike archival data, all published newspaper stories are made publicly available and follow similar reporting and journalistic guidelines.
} 
patterns. ${ }^{10}$ In addition to coding the archival documents, I used these materials, along with newspaper stories, to reconstruct the development of policy debates in each state. This process provided important context for the discourse under discussion.

\section{Results}

Results reveal substantial variation in racialized welfare discourse across the states during the mid-1990s.: The traditional morality discourse about Black work ethic predominated in the South. In the West, this discourse was much less common. My inductive analysis revealed that, in California and Arizona, the morality discourse was supplanted by a law and order discourse, which was applied to Latino and Asian welfare recipients and an economic opportunity discourse which was applied to Native Americans. These types of discourse are distinguished by their underlying assumptions about what causes welfare use. Each discourse was also accompanied by specific policy prescriptions about reducing welfare caseloads (see table 3).

\section{Morality in Welfare Discourse}

\section{Welfare Discourse in the Southern Newspapers}

The newspaper content analysis reveals strikingly similar patterns in welfare discourse in Georgia and Alabama in the mid-1990s (see Table 4). Approximately 24 percent of quotations in the Alabama sample and 20 percent in the Georgia sample of welfare-related news stories employ at least one morality stereotype. This constitutes approximately three welfare stereotypes per welfare-related news story in Alabama and 2.5 in Georgia.

\footnotetext{
${ }^{10}$ Analysis focused on AFDC debates but also included references to Supplemental Nutrition Assistance Program (SNAP or "food stamps") or Supplemental Security Income (SSI, a cash assistance program for the disabled).
} 
The Reagan-era stereotype of the welfare queen characterized welfare recipients as engaged in fraudulent and criminal activity. However, the content analysis shows that in Georgia and Alabama, concerns about the work ethic and family structure of welfare recipients dwarfed worries about their involvement in crime, welfare fraud, and drug use (See table 4). The two most frequently occurring codes in both states were lazy/don't work and pathological family. The third most commonly occurring codes were drain collective resources (Alabama) and teen mothers (Georgia). These findings mirror Hancock's (2004) study which found that national media coverage emphasized the poor work ethic and non-traditional family structures of welfare recipients. Together these results suggest that, to the extent that welfare stereotypes continue to be prominent, welfare discourse has shifted from a focus on criminal involvement to a morality discourse that places blame for welfare receipt on the values and choices of welfare recipients.

The following quote from a Georgia news story exemplifies this focus on the morals rather than criminal behavior of welfare recipients. Bemoaning perceived problems with the country's cash welfare system, one resident stated, "I rarely encounter a welfare recipient who is dying to have a job, to have to get up and go out to work every day in order to have a better life" (Burton 1993), deriding welfare recipients for their lack of work ethic. A 1996 article from the Birmingham News employs both the lazy/don't work and the pathological family frames, but also makes an argument that welfare recipients drain collective resources: "The final group [of people on welfare] is made up of those who refuse to work and basically rely on the hearts of others, especially our 'bighearted' government, to pay for their unwise spending and illegitimate children" (Clark 1996). Such arguments blame the moral failings of welfare recipients, as well the welfare system, for enabling perceived welfare dependency. 
To assess the potential racial undertones of this morality discourse, I coded for explicit references to racial categories and measured the frequency with which each racial code cooccurred with a welfare queen stereotype code (see table 5). In both states negative welfare discourse overwhelmingly focuses on blacks. For example, the following Georgia quotation blames black welfare dependency on a poorly structured welfare system: "Current welfare policy fosters dependency and can cripple poor blacks..." (Serb 1993).

Nearly 100 percent of racialized welfare stereotypes in Georgia and Alabama news stories reference blacks, though the actual TANF caseloads in each state were only 72 percent black in 1996 (ACF 1996, see table 5 and figure 2). The dearth of stereotypes applied to whites may reflect the fact that "white" is an unmarked category in the United States, so direct references to whiteness are quite rare. However, in both Georgia and Alabama welfare news reporting, approximately 25 percent of explicit racial references were to whites. Unlike explicit references to blacks, these references to whites did not accompany welfare stereotypes. These findings suggest that the lack of white welfare stereotypes reflects specific racialized constructions of black poverty rather than a cultural norm of avoiding direct references to whiteness.

To summarize, content analysis demonstrates that welfare discourse in these states in the mid-1990s mirrors the reported trends in national-level discourse wherein media reporting highlights the perceived moral failings of welfare recipients and focuses primarily on Black recipients (Hancock 2004). Public discourse characterized black welfare recipients as lazy individuals who make poor decisions about reproduction and work, marking a change from the fraud-driven characterizations of the Reagan-era. This morality discourse identifies the moral 
failings of poor blacks and an ill-designed cash welfare system as the primary explanations of welfare participation in these states.

\section{Morality Discourse in Southern Policy}

Archival analysis revealed that policymakers in Georgia and Alabama, like the media, routinely invoked the morality discourse to blame poverty and welfare receipt on the failings of black welfare recipients and a problematic welfare system. However, a close look at legislative testimonies, hearing transcripts, and policymakers' private files highlights consequential patterns not found in the media content analysis. First, policymakers largely applied this morality discourse to participants in AFDC and TANF. Second, because policymakers blamed welfare participation on individuals and on welfare programs, this morality discourse validated punitive welfare policies as the appropriate solution to the problem of welfare dependency.

Records and personal accounts from committee debates and legislative hearings confirm the ubiquity of the racialized morality discourse. When asked in an interview to recount the arguments made during welfare reform hearings in Alabama, Michael Sznajderman, a reporter who covered the capitol beat in Montgomery, said that lawmakers viewed welfare recipients as "blacks [who were] just sucking at the government's breast" (Sznajderman 2009). Highlighting what she thought to be the moral failings of black welfare recipients, Martha Nachman, the head of the state's Department of Human Resources caricatured the state's typical welfare recipient as "a 15 year old pregnant with the third kid and addicted to crack" (Forrister 2009). These comments reveal the prevalence of beliefs about the moral failings of welfare recipients as the source of poverty and welfare participation. 
Local residents also used this morality discourse when they wrote to their elected officials. One Georgia resident wrote in a letter to Governor Zell Miller, "The 'AFROAMERICANS' think society owes them something today... We freed them from being slaves, is that not enough? What are we supposed to do? Feed all of them, pay for everything they want? They are just as good as everybody else to go work for what they want (Constituent B 1993). Lawmakers used similar arguments to press for AFDC reforms in their states, demanding that the new cash assistance program, TANF, require welfare recipients to participate in work-related activities as a condition for receiving assistance and deny benefit increases to women who have additional children while on welfare. In an interview, Alabama Representative Jim Carns said, "We didn't want you sitting there are not wanting a job and not wanting to be trained to have a job. And let your child watch you do that because the child grows up and does the same thing the parent does" (Carns 2009). Georgia lawmakers echoed these sentiments; in a memo to the state legislature, Governor Miller said that "welfare [should demand] the same level of responsibility [from recipients] that it requires from the taxpayers" (Miller 1993, 1). New regulations, like work requirements, were framed as the only legitimate way to promote individual responsibility among the poor.

The morality discourse was so prominent in these states that opponents of punitive reforms were forced to engage with it in their protests. When the Georgia branch of the National Organization for Women issued a policy brief on welfare reform, the organization asserted that the "job requirement [in the bill] is being proposed because many people think that mothers receiving AFDC are lazy and do not want to work. The fact is, families do not need to be forced to work" (National Organization for Women 1997, 2). Other advocates challenged the racial underpinnings of the discourse, declaring, as one did in an op-ed feature, that punitive welfare 
reform efforts are "racist and condescending" (Hart 1995). These advocates responded directly to the morality discourse, evidencing its saturation of political debates and its connection to calls for strict limits on welfare participation.

\section{Morality Welfare Discourse in Arizona and California Newspapers}

Media content analysis reveals that welfare discourse was more complex in California and Arizona. Like in Georgia and Alabama, the lazy/don't work and pathological family codes are among the most frequently occurring, joined by drain collective resources. These findings suggest some coherence in welfare discourse across diverse localities. However, there is substantial variation in the prevalence of the morality discourse across the states. As Table 4 shows, only 10 percent of quotations from California and Arizona newspapers contain a traditional welfare stereotype, versus nearly 25 percent of quotations from Alabama and Georgia. ${ }^{11}$ These results suggest that the morality discourse may only predominate when welfare beneficiaries are presumed to be black.

In the 1990s, discourse of welfare recipient laziness and fertility was less common in Arizona and California, and when it was used it was sometimes applied to non-black racial minorities. (see table 5). For example, media content analysis results show that traditional welfare stereotypes are more likely to accompany discussions of Asians in California than in the other three states. For example, the following Los Angeles Times quotation referenced Asians and displayed the themes pathological family and system abuser: "With the use [of] state welfare money, the Hmong men are practicing a tradition of their culture that includes children giving birth to children. This practice points out the need to control reproduction of the poor and

\footnotetext{
11 These differences were present despite the fact that public opinion poll data at the time showed that the citizens of Alabama, Georgia, Arizona, and California were equally supportive of punitive welfare policies (National Election Survey 1996), suggesting that the sources of welfare disapproval were different in the four states.
} 
especially poor immigrants. They abuse our welfare system...” (Norman 1993). In California, one quarter of racialized welfare stereotypes reference Asians, but Asians comprised just 8 percent of the caseload.

In Arizona and California, Hispanics are the most commonly mentioned racial category in the welfare news dataset; however, they are mentioned in different ways. Arizona news quotations are more likely than California stories to chastise Hispanic welfare recipients. For example, this Arizona quotation derides Hispanic welfare recipients for their hyper-fertility and misuse of the welfare system: "My neighbor was trying to rent his house for \$1,100 a month. Well, here comes this Mexican lady with three bambinos and pregnant with a fourth. He asked her how she would pay, and she said 'no problem' and started talking about all this Section 8 and AFDC money she was getting” (Shaffer 1994). In California and Arizona, the percentage of welfare stereotypes applied to Hispanics is similar to their actual welfare up-take rates. In 1996, Hispanics constituted close to 40 percent of welfare recipients in each state and approximately 45 percent of racialized welfare stereotypes (ACF 1996).

California and Arizona differed in their discourse about Native Americans. In Arizona, Native Americans accounted for 15 percent of AFDC recipients but 36 percent of all welfare stereotypes. These stories tend to focus on the connection between casinos and welfare: "Indian casinos have created more than 10,000 tax-paying jobs ... and saved the state an estimated $\$ 7$ million last year by taking people off welfare rolls and putting them on payrolls" (Prescott 1993). In all four states, welfare stereotypes were overwhelmingly applied to racial minorities, not to whites. Whites are underrepresented in welfare discourse given their participation rates. In fact, in Arizona and California not a single quotation applied a welfare stereotype to whites, even though whites comprise over 30 percent of each state's caseload (ACF 1996). In Arizona and 
California, compared to actual welfare caseloads, Native Americans are overrepresented in quotations containing welfare stereotypes. Blacks were also overrepresented in Arizona (figure 2).

These findings provide evidence of substantial variation among states in racialized welfare stereotypes. However, the morality stereotypes believed to characterize welfare discourse across the country are far less prevalent in the western states than in the South. These results may indicate a more favorable discourse about welfare recipients in the western states, but the next section presents archival evidence showing that the morality discourse was supplanted by two alternative racialized discourses. That is, the limited use of the morality discourse in Arizona and California reflects not less racialization of welfare debates but different types of racialized discourse, what I characterize as a law and order discourse and an economic opportunity discourse.

\section{Law and Order Discourse in the West}

Archival records indicate that California and Arizona policymakers primarily maligned welfare recipients for legal transgressions such as immigration violations. However, California and Arizona policymakers in 1993-1997 racialized this discourse differently. Arizona's law and order discourse explicitly referred to Hispanic immigrants, primarily addressing AFDC participation and characterizing Latinos as immigrants who were illegally using cash welfare benefits. In California, the law and order discourse focused largely on Asian welfare recipients. When debates about Asian welfare use arose, policymakers switched from discussing AFDC to discussing SSI, largely ignoring the sizable Asian AFDC and non-Asian SSI recipient 
populations. This discourse also blamed the families of welfare recipients for violating immigration laws and illegally enrolling elderly Asian immigrants in these programs. ${ }^{12}$

During Arizona's welfare reform debates, the law and order discourse identified immigration, particularly undocumented immigrants and lax immigration enforcement as the cause of welfare dependency. For example, one Arizona newspaper reported a deceptive scheme in which Mexican immigrants managed to obtain welfare benefits in Arizona through the use of fraudulent documents: "The way the deception works, a Mexican mother will bring her children across the border and enroll them in [school], using the address of an Arizona relative as the family home. The family then applies for social services using false documents" (Associated Press 1995). In a newspaper article circulated to policymakers, one anti-immigrant advocate said, "We have a hemorrhage of people across our southern border... costing taxpayers dearly in money spent on... welfare... [Some say] a wall would reinforce 'the racist stereotype of Mexican immigrants as criminals.' To me an 'immigrant' is someone who abides by the rules of both countries before he crosses the border... Otherwise, he is, in fact, a criminal" (Holland 1993). The morality discourse prescribes restrictive welfare reforms as a solution to Alabama and Georgia's social problems, but in Arizona, the law and order discourse about Hispanic welfare recipients accompanied intensive debate about immigration enforcement. In the course of welfare reform debates, policymakers and activists regularly called for stricter border and immigration enforcement as the solution to lowering welfare expenditures. For example, one Phoenix advocate asserted in a letter to the editor, "Illegal aliens stream across our porous borders for jobs, to rob and to assault our citizens, and to use our welfare, hospitals and

\footnotetext{
${ }^{12}$ My results also show that policy elites in California demonized illegal immigrants for their legal transgressions, but that this discourse was not explicitly racialized. While many have asserted the implicit racialization of this discourse, particularly in the 1990s (HoSang 2010; Jacobson 1993; Ono and Sloop 2002), this paper only analyzes the explicit racialization of welfare discourse because implicit and explicit references to race have very different policy effects (Mendelberg 2001).
} 
schools... Solutions? Counterfeit-proof and temper-proof worker ID cards. A "1-800-U-RLEGAL" number that employers can use to verify documents... A massive increase in the Border Patrol, augmented by the National Guard. A 12-foot-high trench wall and fence at the border" (Taylor 1994). The Hispanic-centered law and order discourse accompanied calls for strict immigration enforcement more than demands for policies to regulate the perceived permissive behaviors of welfare recipients.

In California, where Asians constituted 9 percent of the population in 1996 (ACF 1996), welfare opponents also employed the law and order discourse when discussing Asian welfare recipients. The Asian-centered discourse differed from the Hispanic-centered one in two respects. First, despite the fact that only a slightly higher percentage of Asians were SSI recipients than AFDC participants, California legislators and advocates characterized Asians as SSI recipients, thereby distancing Asians from the morality discourse that is associated with AFDC use. Second, the assumed cause of welfare use differed between the two types of discourse. When anti-welfare advocates targeted Asian welfare users in California, they blamed the extended families of welfare recipients who had failed to fulfill their promise to support their newly arrived immigrant relatives. Many chided middle-class Asian families who illegally signed elderly relatives up for welfare just to reap the financial rewards (Wong 1999). They also chastised the legal sponsors of new Asian immigrants for reneging on their promise to care for their aging relatives.

Policymakers in Sacramento routinely employed this family-centered law and order discourse during welfare reform debates. The two most common reasons given in news reports for denying welfare benefits to non-citizens were that immigrants were fraudulently receiving benefits despite their families' solid socioeconomic status and the immigrants were coming to 
the United States specifically to reap welfare benefits (Yoo 2001). Summarizing this discourse, scholar William Wong (1999) reported that, "in 1996, a new villainous image emerged to supplement that of the former welfare queen. This image was of an elderly Chinese immigrant undeservedly getting Supplemental Security Income (SSI). This foreign-looking senior citizen should be supported by his or her middle-class children and not by the U.S. Treasury, the image implied. Thus was born a new kind of welfare cheat." Roy Ashburn, a central figure in the state's Republican Caucus, asserted in the legislature that "we [Republicans] do have some... concerns... in respect to providing benefits to legal immigrants, who come to this country under sponsorship, and then expect to be provided with welfare benefits" (Ashburn 1997). These quotations demonstrate notable differences in comparison to the law and order discourse applied to Hispanics in Arizona. They focus on SSI rather than AFDC, despite the fact that Mexican immigrants comprised a larger percentage of SSI recipients than any other immigrant group (Dunn 1995). They also shift blame away from the individual recipient and onto the recipient's sponsoring family.

This family-centered law and order discourse also accompanies different proposed solutions for welfare use: a crackdown on immigrant sponsors and new restrictions on family reunification policies. In his Congressional testimony, Norman Matloff (1996), a professor at the University of California, Davis, asserted,

The immigrant Chinese senior welfare recipients do not need the money. This is true by definition, because at the time a senior immigrates, his/her children must demonstrate to the Immigration and Naturalization Service (INS) that they have the financial resources to be able to support the parent... The noble intentions of "family-reunification" provisions under which the children sponsor their elderly 
parents to immigrate often bear little or no resemblance to reality... The children who do have their elderly parents living with them often actually make a profit from their parents' SSI checks... Our conclusion will be that the only effective solutions will require some restrictions on family-reunification immigration, especially concerning elderly parents, in concert with other measures.

This testimony characterizes Asian-American welfare recipients as victims while disparaging their extended families. It also asserts that immigration reform, not restrictive welfare reforms, would resolve the problem at hand. If discourse about black and Hispanic welfare use "blamed the victims" for their poverty, the discourse around Asian-American welfare use placed blame on their families.

\section{Economic Opportunity Discourse in the West}

Welfare discourse about Native Americans in Arizona cohered around a third perceived cause for welfare participation, a lack of economic opportunity. This discourse connected Native American welfare use to the economic underdevelopment of reservations. This AFDC-focused discourse argues that Native American communities suffered from isolation, limited investments in Native economies, and a history of persecution, resulting in welfare uptake.

During welfare reform debates, this economic opportunity discourse accompanied arguments about casino expansion. For example, both casino and welfare advocates used Arizona's Fort McDowell Reservation to demonstrate the close connection between tribal gaming and cash welfare. One news story reported that, "Unemployment, which plagued nearly one-third of the tribe before the casino windfall, is virtually unheard of. And state welfare payments once collected by one-fourth of the tribal members, are part of Fort McDowell's past" 
(Editorial 1995). One Native American advocate in a political debate said, "Indian people must first be allowed to stand on their feet... there are clear social benefits linked to tribal gaming: it takes people off welfare rolls, creates tax-paying jobs and provides a means of self-sufficiency for Indian people" (Prescott 1993). Citing limited economic development and high rates of welfare use on reservations, political leaders across the state asserted that economic policies, specifically those restricting gaming on reservations, promoted welfare use and denied economic opportunities to Arizona's Native Americans.

The economic opportunity discourse is typically accompanied by calls for the expansion of casinos on reservations and for extended welfare benefits for Native Americans unable to find work. Expansion, according to advocates, "is important in special-needs areas, such as the Navajo and Hopi reservations and in certain other rural communities where jobs are scarce" (Van Der Werf 1993). The economic opportunity discourse, thus, cites structural causes for Native American poverty and welfare use, suggesting structural remedies rather than policy changes targeted at individual behaviors.

\section{Summary and Conclusion}

Research on the racial politics of welfare largely assumes that stereotypes about blacks propel welfare politics in a punitive direction (Gilens 1999; Hancock 2004; Katznelson 2005; Quadagno 1996). This article unearths variation in the content and prevalence of stereotypes in welfare discourse. In Alabama and Georgia newspapers, welfare discourse followed predicted patterns, relying on a morality discourse that emphasized the moral failings of black welfare recipients and suggested policy solutions that target the presumed behaviors of welfare recipients. The morality discourse was also evident, in a much more limited way, in Arizona and California, 
where Hispanics, Asians, and Native Americans were more likely to be the focus of welfare debates. While this morality discourse undergirded the punitive welfare reforms which swept through the country in 1996, it is far from the only racialized discourse in operation.

In Arizona and California, at least two other racialized discourses were politically salient. In Arizona, policymakers and the media employed a discourse centered on law and order to condemn Hispanic immigrants seeking public assistance. This discourse targeted the shortcomings of federal immigration enforcement and the illegal transgressions of recipients. Welfare foes in California used a modified version of this same discourse to blame Asian welfare recipients' families for the welfare participation of Asian immigrants. Arizona welfare opponents employed yet a third discourse to characterize Native American welfare use, one about "economic opportunity". This discourse emphasized that Native American welfare use resulted from limited employment opportunities on reservations and weak public investment in tribal economies.

These distinct types of welfare discourse identified specific causes of welfare use and accompanied calls for specific solutions. The morality discourse identifies the moral failings of welfare beneficiaries as the cause of welfare participation. This discourse was paired with calls for stringent welfare policies, such as strict time limits or family caps, to modify the behavior of recipients. On the other hand, the law and order discourse and the economic opportunity discourse accompanied demands for immigration reforms and economic development, respectively. It is worth noting that these different discourses did not neatly fit policy outcomes. While Georgia rapidly adopted some of the country's most restrictive time limit, sanction, and work requirement TANF regulations in 1997, Alabama, until the early 2000s, adopted the most lenient policies allowed by federal law (Brown Forthcoming). Arizona and California both 
pursued strict immigration reforms in the mid to late 1990s, even suing the federal government for incurred immigration costs (Sontag 1994). Arizona also granted Native American tribes substantial flexibility in negotiating TANF requirements (Cornell et al. 2001). However, while California adopted some of the country's most expansive welfare programs after the federal welfare reforms, Arizona took a more punitive approach, enacting more restrictive time limits, sanctions, and work policies than federally required (Brown 2013). These policy outcomes suggest that racialized welfare discourses become policy-relevant in concert with other political, economic, or institutional forces, a topic worthy of future research.

Nonetheless, these findings are consequential for understanding the complicated relationship between race relations and American politics. Researchers have long recognized that welfare discourses and policies both reflect and create racial inequalities (Quadagno 1996; Lieberman 1998; Soss, Fording, and Schram 2011). The present study suggests that while blacks appear to face more welfare stigma than other groups, the tendency of welfare politics to produce and exacerbate inequality stretches beyond the black-white divide. Future research should assess the discourse that surrounds white welfare use and examine whether discourse about Asian and Hispanic welfare use varies depending on the national origin or immigration status of the perceived beneficiaries. Additionally, because the states analyzed in this study are not necessarily representative of other states, additional research is necessary to examine how racialized welfare discourse relates to policy in other areas. This inquiry is particularly important in new, so-called destination states like North Carolina and Tennessee which have, unlike California and Arizona, experienced a dramatic influx of immigrants in recent years (Massey 2008). 
This analysis also suggests a necessary shift in survey-based analyses of welfare opinion. Existing research typically assumes that the same stereotypes about black welfare recipients apply to Hispanics, just with less intensity (Fox 2004; Soss, Fording, and Schram 2011). The present study suggests that this is only half the story. Welfare stereotypes and discourses are contingent on both race and place. The types of discourse employed in welfare politics differ depending on the race of perceived welfare beneficiaries and the social construction of these beneficiaries. Welfare discourse about non-black racial minorities, then, may be just as powerful but take different forms and have different consequences. Shifts in US racial demographics warrant more analysis of welfare politics beyond the black-white divide (Fox 2004; Reese and Ramirez 2002). The present study indicates that researchers must adequately account for the complex nature of racialized welfare discourse in order to assess its prevalence and its political effects. 


\section{$\underline{\text { References }}$}

ACF, Administration for Children and Families. 1996. "Characteristics and Financial Circumstances of AFDC Recipients, FY 1996”. Washington, DC: Office of Planning, Research and Evaluation, Administration for Children and Families, Department of Health and Human Services.

Ashburn, Roy. 1997. "Confidential Letter to Curt Pringle: Little 4 - Welfare”. Roy Ashburn Papers, California State Archives, Sacramento, CA.

Associated Press. 1995. "Postal Boxes Tools for Welfare Fraud." East Valley Tribune, April 10.

Best, Rachel. 2010. "Situation or Social Problem: The Infuence of Events on Media Coverage of Homelessness." Social Problems 57 (1) (February): 74-91.

Brown, Hana E. Forthcoming. "Racialized Conflicts and Policy Spillover Effects: Welfare Reform Politics in Georgia and Alabama." American Journal of Sociology

- 2013. "Race, Legality, and the Social Policy Consequences of Anti-Immigrant Mobilization." American Sociological Review 78 (2): 290-314.

Burton, Becky. 1993. "Welfare: The American Way (Letter to the Editor)." Atlanta Journal and Constitution, November 16, sec. A19.

Carns, Jim. 2009. "Interview with the Author."

Chavez, Leo R. 2008. The Latino Threat: Constructing Immigrants, Citizens, and the Nation. Palo Alto, CA: Stanford University Press.

Cherlin, Andrew, Bianca Frogner, David Ribar, and Robert Moffitt. 2009. "Welfare Reform in the Mid-2000s: How African-American and Hispanic Families in Three Cities Are Faring." The Annals of the American Academy of Political and Social Science 621 (1) (January): 178-201.

Clark, Richard. 1996. "Should Help Those Who Help Themselves (Letter to the Editor)." Birmingham News, December 23, sec. 4A.

Constituent B. 1993. "Letter to Governor Zell Miller". Governor's Subject Files. Georgia Governor's Office, RG1-1-5, Georgia Archives. Governor's Subject Files. Georgia Governor's Office, RG1-1-5, Georgia Archives.

Cornell, Stephen E., Eddie F. Brown, Leslie Scheuler Whitaker, Melinda Springwater, Miriam Jorgensen, Michelle Hale, and Ami Nagle. 2001. "Welfare, Work, and American Indians: The Impact of Welfare Reform”. St Louis, MO: Binder Center for American Indian Studies.

Curran, Laura. 2002. "The Psychology of Poverty: Professional Social Work and Aid to Dependent Children in Postwar America, 1946-1963." Social Service Review 76 (3) (September): 365-386.

Dunn, Ashley. 1995. "For Elderly Immigrants, a Retirement Plan in U.S.” New York Times, April 16. http://www.nytimes.com/1995/04/16/nyregion/for-elderly-immigrants-aretirement-plan-in-us.html?pagewanted=all\&src=pm.

Editorial. 1995. "Welfare Reform: Kudos to State Lawmakers." Arizona Republic, April 14. Forrister, Kimble. 2009. "Interview with the Author."

Fox, Cybelle. 2004. "The Changing Color of Welfare? How Whites' Attitudes Toward Latinos Influence Support for Welfare.” American Journal of Sociology 110 (3) (November 1): 580-625. . 2012. Three Worlds of Relief: Race, Immigration, and the American Welfare State from the Progressive Era to the New Deal. Princeton University Press. 
Fraser, Nancy, and Linda Gordon. 1994. "A Genealogy of Dependency: Tracing a Keyword of the U.S. Welfare State.” Signs 19 (2): 309-336.

Frey, William H. 2011. "The New Metropolitan Minority Map: Regional Shifts in Hispanics, Asians, and Blacks from Census 2010". Washington, D.C: Brookings Institutions.

Gilens, Martin. 1999. Why Americans Hate Welfare: Race, Media, and the Politics of Antipoverty Policy. Chicago, IL: University of Chicago Press.

Gordon, Linda. 1994. Pitied but Not Entitled: Single Mothers and the History of Welfare. Free Press.

Hagan, Jacqueline, Nestor Rodriguez, Randy Capps, and Nika Kabiri. 2003. "The Effects of Recent Welfare and Immigration Reforms on Immigrants' Access to Health Care." International Migration Review 37 (2): 444-463.

Hancock, Ange-Marie. 2004. The Politics of Disgust: The Public Identity of the Welfare Queen. New York, NY: New York University Press.

Haney, Lynne, and Miranda March. 2003. "Married Fathers and Caring Daddies: Welfare Reform and the Discursive Politics of Paternity." Social Problems 50 (4) (November 1): 461-481.

Hart, Renee. 1995. "1,000 Timely Words.” Atlanta Journal and Constitution, September 27.

Holland, Michael. 1993. "This Country Can't Afford to Be Rich Uncle to the World." Arizona Republic, July 2.

HoSang, Daniel Martinez. 2010. Racial Propositions: Ballot Initiatives and the Making of Postwar California. Berkeley, CA: University of California Press.

Jacobson, Wendy. 1993. "Miller Plan Gives Needy Little Hope.” The Atlanta Journal and Constitution, January 31 , sec. G.

Katznelson, Ira. 2005. When Affirmative Action Was White: An Untold History of Racial Inequality in Twentieth-Century America. New York, NY: W. W. Norton.

Korteweg, Anna C. 2006. "The Construction of Gendered Citizenship at the Welfare Office: An Ethnographic Comparison of Welfare-to-Work Workshops in the United States and the Netherlands." Social Problems 13 (3): 314-340.

Lens, Vicki, and Colleen Cary. 2010. "Negotiating the Discourse of Race Within the United States Welfare System." Ethnic and Racial Studies 33 (6): 1032-1048.

Lieberman, Robert C. 1998. Shifting the Color Line: Race and the American Welfare State. Cambridge, MA: Harvard University Press.

Little, Deborah L. 1999. "Independent Workers, Dependable Mothers: Discourse, Resistance, and AFDC Workfare Programs." Social Politics 6 (2): 161-202.

Loprest, Pamela. 2002. "Who Returns to Welfare?" Washington D.C.: Urban Institute.

Mariampolski, Hyman, and Dana C. Hughes. 1978. "The Use of Personal Documents in Historical Sociology.” The American Sociologist 13 (2): 104-113.

Massey, Douglas S. 2008. New Faces in New Places: The Changing Geography of American Immigration. Russell Sage Foundation Publications.

Matloff, Norman. 1996. "Welfare Use Among Elderly Immigrants". Washington, D.C.: U.S. Senate Judiciary Committee, Subcommittee on Immigration. http://heather.cs.ucdavis.edu/pub/Immigration/WelfareUse/WelfareUsageReport/FullNM Report.html\#tth_sEc1.

Mauldon, Jane, Richard Speiglman, and Matt Stagner. 2012. "TANF Child-only Case Characteristics, Dynamics, and Context”. Chicago, IL: Chapin Hall, University of Chicago. 
Mendelberg, Tali. 2001. The Race Card: Campaign Strategy, Implicit Messages, and the Norm of Equality. Princeton, NJ: Princeton University Press.

Miller, Zell. 1993. "Memo to Members of the House of Representatives Regarding Welfare Reform”. Vicki Anne McLennan Papers, 1979-2000. Women's Collection, Special Collections \& Archives, Georgia State University, Atlanta.

Mink, Gwendolyn. 1996. The Wages of Motherhood: Inequality in the Welfare State, 1917-1942. Cornell Univ Press.

Misra, Joya, Stephanie Moller, and Marina Karides. 2003. "Envisioning Dependency: Changing Media Depictions of Welfare in the 20th Century." Social Problems 50 (4): 482-504.

Monnat, Shannon M. 2010. "The Color of Welfare Sanctioning: Exploring the Individual and Contextual Roles of Race on TANF Case Closures and Benefit Reductions." The Sociological Quarterly 51 (4): 678-707.

Morello, Carol, and Ted Mellnik. 2012. "Census: Minority Babies Are Now Majority in United States.” Washington Post, May 17. http://articles.washingtonpost.com/2012-0517/local/35458407_1_minority-babies-census-bureau-demographers-whites.

National Election Survey. 1996. "National Election Survey". American National Election Studies.

National Organization for Women. 1997. “Georgia NOW Wants Real Welfare Reform”. Vicki Anne McLennan Papers, 1979-2000. Women’s Collection, Special Collections \& Archives, Georgia State University, Atlanta.

Neubeck, Kenneth J., and Noel A. Cazanave. 2001. Welfare Racism: Playing the Race Card Against America's Poor. New York, NY: Routledge.

Norman, Robert Maple. 1993. "Hmong." Los Angeles Times, May 18.

Ono, Kent A., and John M. Sloop. 2002. Shifting Borders: Rhetoric, Immigration, and Californa's Proposition 187. Philadelphia, PA: Temple University Press.

Park, Yoosun, and Susan P. Kemp. 2006. "'Little Alien Colonies': Representations of Immigrants and Their Neighborhoods in Social Work Discourse, 1875-1924." Social Service Review 80 (4) (December): 705-734.

Prescott, Leonard. 1993. "It's Time to Let Indian People Manage Their Own Affairs.” Arizona Republic, May 20.

Quadagno, Jill. 1996. The Color of Welfare: How Racism Undermined the War on Poverty. New York, NY: Oxford University Press.

Reese, Ellen. 2005. Backlash Against Welfare Mothers: Past and Present. Berkeley, CA: University of California Press.

Reese, Ellen, and Elvia Ramirez. 2002. "The New Ethnic Politics of Welfare: Struggles Over Legal Immigrants' Rights to Welfare in California.” Journal of Poverty 6 (3): 29.

Schram, Sanford F. 1995. Words Of Welfare: The Poverty of Social Science and the Social Science of Poverty. University of Minnesota Press.

Scott, John. 1990. A Matter of Record: Documentary Sources in Social Research. Polity Press. Serb, Christopher. 1993. "Letter to the Editor." Atlanta Journal and Constitution, October 3.

Shaffer, Mark. 1994. "California Considers a Lid for Melting Pot: Proposition 187 Targets Illegal Aliens." Arizona Republic, October 23.

Sontag, Deborah. 1994. "3 Governors Take Pleas On Aliens to the Senate." New York Times, June 23.

Soss, Joe, Richard C. Fording, and Sanford F. Schram. 2011. Disciplining the Poor: Neoliberal Paternalism and the Persistent Power of Race. Chicago, IL: University of Chicago Press. 
Soss, Joe, Sanford F Schram, Thomas P Vartanian, and Erin O'Brien. 2001. "Setting the Terms of Relief: Explaining State Policy Choices in the Devolution Revolution." American Journal of Political Science 45 (2): 378-395.

Staff Writer. 1976. “'Welfare Queen' Becomes Issue in Reagan Campaign.” New York Times, February 15.

Sznajderman, Michael. 2009. "Interview with the Author."

Taylor, Thomas. 1994. "Winners, Losers of Immigration." Arizona Republic, July 2, sec. B7.

Toft, Jessica. 2010. "The Political Act of Public Talk: How Legislators Justified Welfare Reform." The Social Service Review 84 (4) (December): 563-596.

Van Der Werf, Martin. 1993. "Governors Target Gaming." Arizona Republic, March 9.

Watkins-Hayes, Celeste. 2009. "Race-Ing the Bootstrap Climb: Black and Latino Bureaucrats in Post-Reform Welfare Offices.” Social Problems 56 (2) (May 1): 285-310.

Weaver, R. Kent, and Thomas Gais. 2002. State Policy Choices Under Welfare Reform. Washington, DC: Brookings Institution.

Weir, Margaret. 1990. Politics and Jobs. Princeton, NJ: Princeton University Press.

Wong, William. 1999. "Asian-Americans and Welfare Reform.” Nieman Reports. http://www.nieman.harvard.edu/reportsitem.aspx ?id=102222.

Woodward, Kerry. 2008. "The Multiple Meanings of Work for Welfare-Reliant Women." Qualitative Sociology 31 (2): 149-168.

Yoo, Grace. 2001. "Shaping Public Perceptions of Immigrants on Welfare: The Role of Editorial Pages of Major U.S. Newspapers." International Journal of Sociology and Social Policy 21 (7): 47-62. 
Figure 1: AFDC Caseloads by Race, 1996



Source: ACF 1996 


\section{Table 1: Welfare Stereotype Codes}

Component

Drain Collective Resources

Lazy/Don't Work

Long-Term Dependency

Overly Fertile

Pathological Family

Drug Users

Crime

Teen Mothers

Education

System Abusers

Inner-City Resident
Definition

Cash welfare takes up too much of the budget at the expense of "legitimate" groups

Welfare recipients do not work and are lazy

Welfare recipients remain on welfare too long, and their children will grow up to be on welfare

Welfare mothers have too many children even though they cannot afford them; they receive more benefits from having these children

Welfare families are single-parent families or families with illegitimate children; welfare policy encourages out of wedlock births

Many welfare recipients have current or past problems with drug abuse

Many welfare users perpetuate crimes

Most welfare recipients are teen mothers

Welfare recipients are poorly educated and don't care about pursuing education

Most welfare recipients are cheating the system or engaging in welfare fraud

Most welfare recipients reside in the inner-city 


\section{Table 2: Racial Codes}

Code

Asian

black/African-American

Latino/Hispanic

Native

white

\section{Defined Terms}

Use of terms Asian or Asian American; References to

individuals from Asian countries

Use of terms black, African-American, Negro

Use of terms Latino/a, Hispanic, and references to individuals from Central and South America

Use of terms Native American, American Indian, Indian, and reference to individual U.S. tribes

Use of terms white, Anglo, Caucasian, Anglo-Saxon 


\begin{tabular}{|c|c|c|c|c|}
\hline \multicolumn{5}{|c|}{ Table 3: Welfare Discourse Attributes } \\
\hline Discourse & Applied to & Program & Cause/Blame & Solution \\
\hline Morality & blacks & AFDC/TANF & Recipients; permissive system & Strict welfare policies \\
\hline \multirow{2}{*}{ Law and Order } & Latinos (Arizona) & AFDC/TANF & Lax border enforcement & Immigration enforcement \\
\hline & Asians (California) & SSI & Weak immigration enforcement & Immigration enforcement \\
\hline Economic Opportunity & Native Americans & AFDC/TANF & Lack of economic opportunities & Investment in jobs \\
\hline
\end{tabular}




\section{Table 4: Morality Stereotype Prevalence}

\begin{tabular}{lcccc} 
& Alabama & Georgia & Arizona & California \\
& & & & \\
$\begin{array}{l}\text { Quotations with Any Welfare Stereotype } \\
\text { (\% of all quotations) }\end{array}$ & 758 & 625 & 415 & 409 \\
& $(24 \%)$ & $(20 \%)$ & $(10 \%)$ & $(10 \%)$ \\
Distribution of Stereotype Codes ${ }^{13}$ & & & & \\
Lazy/Don't Work & & & & \\
Pathological Family & $26 \%$ & $26 \%$ & $20 \%$ & $22 \%$ \\
Drain Collective Resources & $17 \%$ & $25 \%$ & $14 \%$ & $21 \%$ \\
Teen Mothers & $15 \%$ & $5 \%$ & $16 \%$ & $13 \%$ \\
Long Term Dependency & $7 \%$ & $11 \%$ & $12 \%$ & $6 \%$ \\
Education & $9 \%$ & $7 \%$ & $13 \%$ & $7 \%$ \\
Drug Users & $8 \%$ & $10 \%$ & $8 \%$ & $4 \%$ \\
System Abuser & $3 \%$ & $3 \%$ & $4 \%$ & $7 \%$ \\
Crime & $6 \%$ & $3 \%$ & $4 \%$ & $6 \%$ \\
Overly Fertile & $2 \%$ & $3 \%$ & $4 \%$ & $6 \%$ \\
Inner City & $3 \%$ & $4 \%$ & $4 \%$ & $4 \%$ \\
\hline Total & $3 \%$ & $2 \%$ & $1 \%$ & $3 \%$ \\
\hline
\end{tabular}

${ }^{13}$ Base for each figure is the total number of quotations containing a welfare stereotype. For example, $26 \%$ of Alabama's welfare stereotypes were about laziness and lack of work ethic. 


\section{Table 5: Percentage of Stereotype Codes}

Containing a Racial Marker ${ }^{14}$

\begin{tabular}{rcccc} 
& Alabama & Georgia & Arizona & California \\
Asian & $0 \%$ & $0 \%$ & $0 \%$ & $29 \%$ \\
black & $93 \%$ & $100 \%$ & $18 \%$ & $14 \%$ \\
Latino & $0 \%$ & $0 \%$ & $45 \%$ & $43 \%$ \\
Native & $0 \%$ & $0 \%$ & $36 \%$ & $14 \%$ \\
white & $7 \%$ & $0 \%$ & $0 \%$ & $0 \%$ \\
\hline total & $100 \%$ & $100 \%$ & $100 \%$ & $100 \%$
\end{tabular}

\footnotetext{
${ }^{14}$ Base for each state is the number of stereotype codes containing a racial marker. For example, of the Georgia stereotype codes containing a racial marker, $100 \%$ of those racial markers were about Blacks.
} 
Figure 2: Actual Demographics of Welfare Rolls in 1996 versus Racialized Welfare Stereotypes in News Stories*



*"Racialized welfare stereotypes" refers to the percentage of stereotype codes co-occurring with a race code (Table 5).

Source: ACF 1996 